\title{
PERANCANGAN DESAIN TRADITIONAL SIGN SYSTEM DI AIR TERJUN TIU PITUQ KABUPATEN LOMBOK UTARA
}

\author{
Sandi Justitia Putra ${ }^{1}$, Jazadil Iman ${ }^{2}$ \\ 1, Program Studi IImu Komunikasi, Fakultas Ilmu Sosial dan IImu Politik, Universitas 45 Mataram \\ 2, Program Studi Desain Komunikasi Visual, fakultas Teknik dan Ilmu Komputer, Universitas Bumigora \\ sandijustitiaputra@gmail.com ${ }^{1}$, Jazrilumam6800@gmail.com ${ }^{2}$
}

\begin{abstract}
Abstrak
Kabupaten Lombok Utara adalah salah satu kabupaten di Provinsi Nusa Tenggara Barat yang dikenal dengan keindahan destinasi wisatanya. Salah satunya adalah wisata air terjun Tiu Pituq yang resmi dibuka pada tahun 2017. Lokasi wisata ini merupakan ekowisata yang mengutamakan aspek lingkungan dan keindahan alam. Sebagai salah satu obyek wisata yang memiliki luas \pm 2 hektar tentunya wisata air terjun Tiu Pituq memerlukan sign system yang informatif dan komunikatif untuk para wisatawan yang berkunjung. Tujuan dari penelitian ini adalah untuk menciptakan desain sign system yang dapat menyampaikan informasi secara tepat dan memiliki ciri khas tradisional serta memiliki daya tarik tinggi sehingga para wisatawan yang mengunjungi dapat menemukan dan menikmati semua fasilitas atau spot-spot yang ada di air terjun Tiu Pituq. Guna mendukung peneliti dalam proses perancangan sign system di lokasi tersebut maka penelitian ini menggunakan metode penelitian kualitatif dengan melakukan wawancara, survei lapangan serta dokumentasi dari lokasi air terjun Tiu Pituq. Adapun hasil dalam Penelitian ini adalah karya desain sign system dengan penerapan konsep tradisional sign system, dengan suasana yang tetap menyatu dengan alam, dimana hal tersebut dapat membuat para pengunjung merasakan atau menikmati suasana alam sekaligus dapat mengetahui cerita rakyat yang terjadi di lokasi wisata tersebut.
\end{abstract}

Kata Kunci: desain, ekowisata, traditional, sign system, tiu pituq

\begin{abstract}
North Lombok Regency is one of the regencies in West Nusa Tenggara Province. It is known for the beauty of its tourist destinations. One of them is the Tiu Pituq waterfall tour, which officially opened in 2017. This tourist location is ecotourism that prioritizes environmental aspects and natural beauty. As one of the tourism objects that have an area of \pm 2 hectares, of course, the Tiu Pituq waterfall tour requires an informative and communicative sign system for tourists who visit. The purpose of this research is to create a sign system design that can convey information accurately and has traditional characteristics and other than has a high attractiveness so that tourists who visit can find and enjoy all the facilities or spots in the Tiu Pituq waterfall. To support researchers in the process of designing sign systems at these locations, this study uses qualitative research methods by conducting interviews, field surveys, and documentation of the Tiu Pituq waterfall. The results of this study are the Sign System design work with the application of the concept of the traditional sign system, an atmosphere that still united with nature, where it can make visitors feel or enjoy the natural atmosphere while being able to know the folklore that occurs at the tourist site.
\end{abstract}

Keywords: design, ecotourism, tiu pituq, traditional, sign system 


\section{PENDAHULUAN}

Nusa Tenggara Barat merupakan Provinsi di Indonesia yang terletak di bagian barat Kepulauan Nusa Tenggara. Provinsi ini beribukota di Mataram dan memiliki 10 Kabupaten/Kota. Salah satunya yaitu Kabupaten Lombok Utara yakni kabupaten yang terletak di sebelah utara pulau Lombok dan berbatasan langsung dengan dua Kabupaten yaitu Kabupaten Lombok Barat dan Kabupaten Lombok Timur. Lombok Utara adalah salah satu Kabupaten yang memiliki banyak kekayaan alam yang menyimpan potensi besar sebagai objek wisata. Jenisnya pun beragam dimulai dari air terjun, desa adat, serta pantai-pantainya yang eksotis. Salah satu destinasi wisata yang cukup terkenal di Kabupaten Lombok Utara bernama wisata air terjun Tiu Pituq yang terletak di Dusun Penjor, Desa Genggelang, Kecamatan Gangga. Wisata yang resmi dibuka sejak awal Januari 2017 ini ditata dengan gaya kekinian sehingga menjadi tujuan wisata yang menarik untuk dikunjungi oleh para wisatawan. Di lokasi wisata ini terdapat 7 spot pemandian yang 4 diantaranya memiliki air terjun, dan beberapa spot foto. Wisata air terjun Tiu Pituq merupakan ekowisata yang mengutamakan aspek lingkungan dan keindahan alam. Selain itu lokasi dan nama tempat wisata Tiu Pituq ini memiliki sejarah yakni pada zaman dahulu di bumi Gangga Genggelang tentang seorang pemuda bernama Arka Sakti Ningrat yang merupakan anak dari Patih Tempang yang mengajak seluruh masyarakat dan para sesepuh adat untuk mandi bersama di Tiu Pituq dengan tujuan menghilangkan kasta atau penyetaraan derajat di antara mereka".

Sebagai salah satu obyek wisata yang memiliki luas \pm 2 hektar tentunya wisata air terjun Tiu Pituq ini memerlukan sign system yang informatif dan komunikatif untuk para wisatawan yang mengunjungi lokasi wisata air terjun Tiu Pituq ini. Menurut pengelola tempat wisata Tiu Pituq Sarihi Fidian mengatakan "jumlah pengunjung wisata Tiu Pituq untuk setiap minggu berkisar 500 pengunjung dan sampai dengan bulan oktober 2017 jumlah pengunjung terhitung berjumlah 5400 pengunjung yang dominan diisi oleh wisatawan lokal, namun semenjak terjadinya bencana gempa 7.0 SK yang mengguncang kabupaten Lombok Utara pada 5 Agustus 2018, mengakibatkan sejumlah fasilitas tempat wisata ini rusak, hal ini juga yang mengakibatkan penurunan jumlah pengunjung yang dapat dikatakan signifikan yang pada saat sekarang ini hanya berkisar 100 pengunjung pada setiap minggunya. Banyaknya wisatawan yang menumpuk disuatu spot diakibatkan oleh petunjuk arah yang tidak memadai dan tidak mencerminkan makna ataupun sejarah dari lokasi Tiu Pituq, keterbatasan petunjuk arah ini juga menyebabkan banyak spot ataupun lokasi lain yang tidak dapat dijangkau oleh pengunjung, sehingga dalam hal ini dibutuhkan sign system yang tepat untuk mengatasi permasalahan tersebut.

Sign system didalam konteks komunikasi visual ialah representasi visual yang berguna sebagai media interaksi manusia didalam ruang publik (Tinarbuko, 2012). Sign system dibagi menjadi 4 (empat) bagian yaitu a) Traffic sign adalah sign system yang terdapat di jalan yang berguna untuk memberikan informasi kepada pengguna jalan seperti penunjuk arah, peringatan, dan larangan; b) Commercial sign adalah sign system yang berfungsi komersil; c) Wayfinding sign adalah sign system yang bersifat mengarahkan serta menjadi penunjuk jalan; dan d) Safety sign adalah sign system yang mempunyai 
fungsi untuk menginformasikan pesan yang bersifat peringatan, larangan maupun himbauan guna mengingatkan pengguna mengenai suatu sistem keamanan.

Beberapa jenis sign system di atas dapat digunakan berdasarkan fungsi dan keperluan pembuatnya. Contohnya gedung perkantoran yang yang memiliki area cukup luas dan ruang yang banyak sehingga membutuhkan media penunjuk seperti wayfinding yang dapat diartikan dalam kemampuan untuk menemukan jalan menuju suatu lokasi (Tanuwidjaja, 2012). Untuk menciptakan suatu sign system (wayfinding) yang efektif diperlukan beberapa hal dan langkah mulai dari menetapkan tujuan menentukan jalan, menganalisa profil pengguna, meneliti tingkat kesulitan menemukan jalan, menganalisa kebutuhan desain, menyusun desain sign system, dan yang terakhir mengumpulkan informasi yang detail dan akurat kedalam sistem grafis. Sign system disini menyampaikan informasi yang bersifat deskriptif karena memang diciptakan untuk membedakan orang dan tempat secara khusus dan jelas. Hal ini dapat dilakukan dengan mengelompokkan tempat dan memberikan nama pada masing-masing tempat atau ruang. Informasi yang terdapat dalam informasi lingkungan adalah merupakan informasi lokasi (Tanuwidjaja, 2012).

Berdasarkan hasil pengamatan lapangan yang telah dilakukan oleh peneliti di lokasi wisata, peneliti menilai sign system yang ada di lokasi wisata tidak dapat berfungsi dengan baik. Hal ini disebabkan karena sign system yang tersedia menggunakan tanda yang relatif banyak sehingga membuat pengguna menjadi kebingungan, selanjutnya peletakan lokasi sign system yang tidak tepat sehingga para pengunjung tidak dapat melihat secara maksimal serta warna dan tekstur sign system yang tidak memadai sehingga mengakibatkan jarak pandang pengunjung pada sign system menjadi tidak maksimal.

Adapun tujuan dari penelitian ini adalah menciptakan desain sign system yang dapat menyampaikan informasi secara tepat dan jelas serta memiliki daya tarik tinggi sehingga para wisatawan yang mengunjungi dapat menemukan dan memanfaatkan semua fasilitas atau spot-spot yang ada di air terjun Tiu Pituq Kabupaten Lombok Utara secara maksimal. Sign system sebagai tanda, yang apabila diartikan secara umum yaitu suatu komunikasi yang dapat berbentuk verbal maupun visual. Keberadaan tanda sangat penting bagi masyarakat dalam fungsi sebagai penyampai atau pengantar informasi. Tanda merupakan ilmu yang tidak bersifat tidak pasti, melainkan sesuatu hal yang terbentuk oleh "pengetahuan" yang lebih terbuka. Yang menjadi sesuatu yang penting dalam sistem tanda yaitu menyampaikan suatu pesan dari pengirim pesan kepada penerimanya, berdasarkan kode tertentu, yang sudah di mediasi dengan media tertentu (Tinarbuko, 2009). Sign system akan mampu menciptakan tanda ataupun penunjuk yang menarik, dan sesuai dengan ikon Tiu Pituq itu sendiri. Sehingga selain sebagai penunjuk arah mempermudah wisatawan menemukan spot-spot yang lain juga menjadi sebagai penyampai informasi sehingga menjadi daya tarik utama bagi para pengunjung jika dikemas ataupun dikonsep dengan semenarik mungkin. 
Penelitian yang berkaitan tentang perancangan sign system sudah banyak diterapkan dan dipublikasi, namun penelitian terkait perancangan traditional sign system khususnya bidang ekowisata yang peneliti terapkan ini sepanjang pengetahuan peneliti belum pernah ada yang menerapkan. Beberapa penelitian terdahulu yang terkait dan menjadi rujukan penulis adalah penelitian dengan judul "perancangan alternatif sign system sebagai informasi lokasi penjualan di pasar Legi Kota Gede" yang dilakukan oleh peneliti Andrijanto. Penelitian ini lebih membahas tentang perancangan sign system di Pasar Legi Kota Gede untuk memudahkan para pembeli untuk mencari tempat maupun arah jalan ke lapak pedagang. Adapun metode penelitian yang digunakan adalah berbasis penciptaan berupa ekplorasi ide, improvisasi / eksperimentasi dan perwujudan (Andrijanto, Mei - Agustus 2018).

Selanjutnya ada penelitian dengan judul "perancangan sign system kampung Madras Kota Medan" yang dilakukan oleh peneliti Muhammad Sabri". Penelitian ini membahas tentang perancangan sign system yang dijadikan sebagai sarana petunjuk (signage) di Kampung Madras, yang diharapkan dapat membantu para pengunjung agar tidak tersesat (Sabri, November 2015). Penelitian lainnya dengan judul "Re-designing sign system in Kiaracondong Railway Station Bandung" yang dilakukan oleh peneliti Ruth Dina Mentari Hutasoit dan I Dewa Alit Dwija Putra. Penelitian ini membahas tentang perancangan sign system yang efektif dan informatif bagi para pengunjung Stasiun Kiaracondong. Adapun metode penelitian dengan cara observasi, studi pustaka, kuesioner dan wawancara (Putra., 2014). Terakhir ada penelitian dengan judul "perancangan media informasi Kota Tua Jakarta Utara melalui sign system yang terintegrasi website" dilakukan oleh peneliti Mohamad Farid Rizqullah dan Wirania Swasty. Penelitian ini membahas tentang perancangan sign system yang terintegrasi dengan website sebagai media informasi untuk kawasan Kota Tua Jakarta dengan penggayaan desain neoklasik. Adapun metode penelitiannya menggunakan metode campuran. Metode pengumpulan data dalam penelitian ini menggunakan wawancara, kuesioner, dan observasi. Sedangkan untuk analisis data menggunakan analisis visual dengan melakukan perbandingan menggunakan matriks tentang visual sign system dan website yang serupa (Swasy, agustus 2019)

\section{METODE PENELITIAN}

\subsection{Metode Penelitian}

Peneliti menggunakan metode penelitian kualitatif dalam penelitian ini. Metode kualitatif merupakan metode analisa yang didasari oleh respon ataupun reaksi dalam bentuk-bentuk verbal oleh khalayak target (Prof. Dr. A. Muri Yusuf, 2016). Analisa data dengan metode kualitatif ini dapat diperoleh dengan meneliti, dan menyebarkan kuesioner tentang perjalan menjelajahi Air Terjun Tiu Pituq ini, dengan tujuan untuk mengetahui kelebihan ataupun kelemahan dari tempat wisata tersebut sehingga menjadi acuan untuk strategi dan pembuatan yang efektif.

\subsection{Metode Pengumpulan Data}

Data dibagi menjadi data primer dan data sekunder. Data primer merupakan data yang diperoleh dari hasil penelitian ataupun pengamatan data di Lapangan, dan dari teori- 
teori yang diperoleh dari sumber-sumber yang dapat dipercaya, baik itu dari internet, buku, surat kabar, hingga data literatur lainnya yang menjadi pendukung proses perancangan sehingga memperoleh informasi yang memadai yang dituangkan dalam visualisasi. Sedangkan data sekunder merupakan data yang diperoleh dari hasil wawancara, survei lapangan serta dokumentasi dari lokasi air terjun Tiu Pituq yang bertujuan untuk untuk mendukung peneliti dalam proses perancangan sign system di lokasi tersebut (Muri, 2017).

\subsection{Metode Analisis Data}

Guna memperkuat perancangan, maka peneliti menggunakan metode analisis data $5 \mathrm{~W}$ $+1 \mathrm{H}$, yakni : What : permasalahan apa yang dibahas?, Where : dimana perancangan sign system itu akan dibuat?, When : kapan perancangan itu akan dilakukan?, Who : siapa target audience dari perancangan sign system tersebut? Why : untuk tujuan apa perancangan sign system itu dibuat?, dan How : bagaimana tahapan perancangan sign system tersebut?

\subsection{Metode Perancangan}

Metode Design Thinking dipopulerkan oleh David Kelley dan Tim Brown pendiri IDEO sebuah konsultan desain yang berlatar belakang desain produk berbasis inovasi. Design Thinking merupakan metode yang memberikan peluang bagi pengguna dan pasar secara menyeluruh, tidak sekedar tampilan dan fungsi (Brown, 2018).

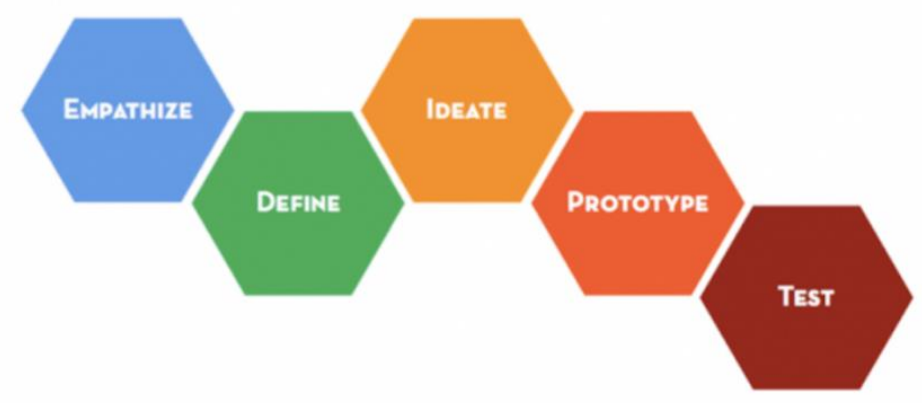

Gambar 1. Metode Design Thinking

[Sumber: google.co.id]

Metode perancangan ini meliputi: (1) Empathize. Dalam tahap ini hal yang dapat dilakukan yaitu survei dan observasi dengan cara terjun langsung ke lokasi air terjun Tiu Pituq, serta dengan melakukan wawancara kepada wisatawan yang berkunjung terkait dengan fasilitas penunjang tempat wisata tersebut. (2). Define. Dalam tahap ini akan menganalisa pokok permasalahan yang menjadi permasalahan inti di air terjun Tiu Pituq. (3) Ideate. Dalam tahap ini mulai menggambarkan solusi yang yang dibutuhkan sesuai dengan hasil observasi dan wawancara permasalahan yang ada. (4) Prototype. Tahap ini mulai membentuk desain sign system yang sesuai dengan permasalahan dan akan diuji coba kepada target audiens/pengunjung. (5) Test. Tahapan ini dilakukan uji coba terhadap desain Sign System yang sudah dibuat, uji coba yang dilakukan untuk mendapatkan respon pengunjung apakah Sign System yang dibuat berhasil atau tidak. 


\section{HASIL DAN PEMBAHASAN}

\subsection{Empathize}

Wisata air terjun Tiu Pituq merupakan salah satu destinasi wisata baru di Kabupaten Lombok Utara yang terletak di Dusun Penjor, Desa Genggelang, Kecamatan Gangga. Wisata yang resmi dibuka sejak awal Januari 2017 ini ditata dengan gaya kekinian sehingga menjadi tujuan wisata yang menarik untuk dikunjungi oleh para wisatawan. Di lokasi wisata ini terdapat 7 spot pemandian yang 4 diantaranya memiliki air terjun, dan beberapa spot foto. Wisata air terjun Tiu Pituq merupakan ekowisata yang mengutamakan aspek lingkungan dan keindahan alam. Selain itu lokasi dan nama tempat wisata Tiu Pituq ini memiliki sejarah yakni pada zaman dahulu dibumi Gangga Genggelang tentang seorang pemuda bernama Arka Sakti Ningrat yang merupakan anak dari Patih Tempang yang mengajak seluruh masyarakat dan para sesepuh adat untuk mandi bersama di Tiu Pituq dengan tujuan menghilangkan kasta atau penyetaraan derajat diantara mereka".

Sebagai salah satu obyek wisata yang memiliki luas \pm 2 hektar, peneliti menemukan bahwa wisata air terjun Tiu Pituq belum memiliki sign system yang informatif dan komunikatif untuk para wisatawan yang mengunjungi lokasi wisata tersebut. Sehingga mengakibatkan banyak wisatawan yang kebingungan saat akan menikmati keindahan wisata Tiu Pituq. Sesuai dengan hasil wawancara peneliti dengan pengelola tempat wisata Tiu Pituq Sarihi Fidian mengatakan "jumlah pengunjung wisata Tiu Pituq untuk setiap minggu berkisar 500 pengunjung dan sampai dengan bulan oktober 2017 jumlah pengunjung terhitung berjumlah 5400 pengunjung yang dominan diisi oleh wisatawan lokal, namun semenjak terjadinya bencana gempa 7.0 SK yang mengguncang kabupaten Lombok Utara pada 5 Agustus 2018, mengakibatkan sejumlah fasilitas tempat wisata ini rusak, hal ini juga yang mengakibatkan penurunan jumlah pengunjung yang dapat dikatakan signifikan yang pada saat sekarang ini hanya berkisar 100 pengunjung pada setiap minggunya. Banyaknya wisatawan yang menumpuk disuatu spot diakibatkan oleh petunjuk arah yang tidak memadai dan tidak mencerminkan makna ataupun sejarah dari lokasi Tiu Pituq, keterbatasan petunjuk arah ini juga menyebabkan banyak spot ataupun lokasi lain yang tidak dapat dijangkau oleh pengunjung, sehingga dalam hal ini dibutuhkan sign system yang tepat untuk mengatasi permasalahan tersebut.

\subsection{Define}

Analisis data yang digunakan dalam penelitian ini adalah $5 \mathrm{~W}+1 \mathrm{H}$ karena dirasa efektif dalam mengidentifikasi seluruh data yang didapat agar perancangan Sign System ini sampai ke target sasaran dengan tepat.

What? Adapun yang akan dirancang oleh peneliti yaitu berupa karya sign system wisata Air Terjun Tiu Pituq. Perancangan sign system ini dibuat dengan konsep anti kejenuhan yaitu dengan mengajak target audience untuk berpetualang dengan bantuan peta sebagai media pembantu untuk mencari sign yang dibentuk dengan ikon yang mewakili dari spot-spot yang ada di lokasi wisata tersebut. 
Who? Adapun target dari hasil perancangan ini adalah para pengunjung wisata Air Terjun Tiu Pituq dari usia 17 sampai dengan 70 tahun ke atas baik laki-laki maupun perempuan.

Why? Adapun alasan yang melatarbelakangi perancangan sign system ini adalah tempat wisata Air Terjun Tiu Pituq merupakan area wisata yang cukup luas yang tergolong wisata kekinian, di samping itu juga memiliki nilai cerita rakyat, maka dipandang perlu untuk merancang sebuah petunjuk arah yang mampu mengarahkan pengunjung secara maksimal. Tujuan dari perancangan sign system ini adalah untuk memberikan petunjuk arah kepada pengunjung atau target audiens sehingga dengan keadaan lokasi wisata air terjun yang cukup luas target audiens dapat menemukan lokasi ataupun spot-spot yang diinginkan tanpa harus takut tersesat ataupun keluar jalur dari lokasi wisata yang sudah disediakan

When? Karya sign system ini akan akan diterapkan setiap hari dan dengan kurun waktu penggunaan selama 4 bulan, sehingga dalam satu tahun akan dilakukan tiga kali pergantian namun tetap dengan desain yang sama.

Where? Karya sign system ini akap dipasang di dalam area lokasi Air Terjun Tiu Pituq Kabupaten Lombok Utara. Tempat pemasangan sign system ini haruslah akurat yaitu dimana titik fokus para pengunjung, disini peneliti merancang untuk pemasangan sign system yaitu di persimpangan jalan menuju spot ataupun fasilitas air terjun yang dituju.

How? Karya sign system ini memiliki konsep berpetualang untuk menjelajahi semua spot dan fasilitas yang sudah disediakan, dalam konsep ini juga dirancang setiap icon yang mewakili tempat dari masing masing spot. Karya sign system dirancang untuk dapat berkomunikasi untuk menyampaikan makna ataupun cerita rakyat yang ada di area Tiu Pituq itu sendiri. Air terjun Tiu Pituq berlokasi di dusun Penjor, kecamatan Gangga yang area lokasi pariwisatanya dapat dikatakan cukup luas karena memiliki 7 air terjun yang lokasinya berbeda, sehingga luas wilayah yang ada didalam area air terjun tersebut \pm 2 Hektar. Dengan mengetahui luas wilayah yang akan dicakup serta pemasangan yang berada di area outdoor dan akan terkena terik matahari dan hujan dengan rentan waktu tidak menentu, maka frekuensi yang dibutuhkan dalam pemasangan sign system adalah tiga kali dalam satu tahun dan menggunakan media kayu menyesuaikan dengan keadaan alam sekitar yang ada disana agar terlihat alami. Kesinambungan konsep desain yang dirancang antara media utama dan media kedua hingga media selanjutnya disini menggunakan warna agak gelap menyerupai serat kayu agar sesuai dengan lokasi penerapan, hal ini dimaksudkan agar ada sinkronisasi antara desain ataupun perancangan yang pertama sampai dengan desain yang selanjutnya.

Adapun jumlah produksi media papan ikon untuk sign system ini berjumlah 7 papan ikon karena mengingat spotnya berjumlah 7 yang akan ditempatkan di ketujuh persimpangan menuju ke masing-masing spot tersebut. Sedangkan untuk media kedua yaitu peta akan dibuat 100 peta. Media utama perancangan sign system air terjun Tiu Pituq ini memiliki fungsi mengarahkan atau memberi arah dengan menggunakan papan 
ikon dan peta dengan ukuran yaitu Tinggi $=175 \mathrm{~cm}$, Lebar $=40 \mathrm{~cm}$, dan untuk media kedua atau media pembantu menggunakan kertas dengan lebar $=29 \mathrm{~cm}$ dan tinggi $=16.5 \mathrm{~cm}$. adapun untuk bahan papan ikon sebagai media utama dari sign system ini adalah kayu nangka dengan tujuan agar adanya sinkronisasi antara konsep bahan dan area pemasangan. Sedangkan teknik visualisasi dari perancangan sign system ini adalah ukir dan di pengecatan atau pemberian warna.

\subsection{Ideate}

\subsubsection{Konsep Kreatif Perancangan Desain Sign System}

Menurut Syiffaun Nafisah (Nafisah, 2003) bahwa perancangan merupakan gambaran, perencanaan dan pembuatan sketsa atau pengaturan dari beberapa elemen yang terpisah ke dalam satu kesatuan yang utuh dan mempunyai makna atau arti. Sedangkan Desain merupakan suatu hasil karya kreatif yang menggabungkan berbagai seni dan arsitektur. Proses desain bukan hanya sekadar perancangan bernilai estetika, akan tetapi untuk melahirkan suatu desain, dibutuhkan pertimbangan pemikiran, rasa, gagasan juga pendapat dari pihak lain. Selain itu penting juga melibatkan faktor internal (yaitu jiwa seni, ide dan kreativitas perancang) atau pun faktor eksternal (berupa hasil penelitian dari berbagai bidang ilmu, teknologi, lingkungan, budaya dan sebagainya.

Dalam perancangan sign system di air terjun Tiu Pituq guna memaksimalkan penggunaan dan kunjungan ke setiap spot-spot yang ada maka perancangan memiliki konsep yaitu petualangan, dimana setiap spot dengan spot lain memiliki jarak yang berjauhan, sehingga dalam perancangan sign system ini audiens atau pengunjung diajak untuk tidak hanya berjalan untuk sampai ke lokasi yang diinginkan namun disini pengunjung diajak untuk mencermati dan mengamati tentang alam sekitar. Pada titik akhir nanti pengunjung akan menemukan spot atau lokasi yang dituju dengan nilai tambah penjelasan tentang lokasi yang dituju (cerita rakyat) yang terjadi di masa lampau di lokasi tersebut.

Tujuan dari perencanaan media yang dibuat ini ialah untuk menentukan media apa yang paling efisien dan efektif, yang memiliki nilai guna, yang mendukung keberhasilan dalam perancangan sign system sesuai dengan target yang diinginkan. Setelah melakukan survey maka dipilihlah kayu yang dengan desain ikon menjadi media utama dan peta menjadi media kedua (pendukung) yang di desain menjadi petunjuk arah yang akan mengarahkan target audiens untuk mencari simbol yang terdapat pada media utama di masing-masing spot yang ada, dan setelah itu target audiens akan menemukan spot yang terdapat pada peta dengan papan penjelasan spot yang telah ditemukan tersebut. Tentunya media utama pada perancangan tidak akan berhasil jika tidak ada media pendukung, disini media pendukung sangat dibutuhkan juga karena pada setiap perancangan yang dibuat mulai dari media utama sampai dengan media seterusnya akan memiliki kesinambungan sehingga dalam hal ini saling mengisi atau membutuhkan. Dalam perancangan sign system ini dibutuhkan dua media pendukung yaitu peta dan tiket masuk. 
Adapun tema dari konsep perancangan sign system air terjun Tiu Pituq ini adalah "MENJELAJAH" mengajak pengunjung ataupun target audiens untuk menikmati dan merasakan keindahan alam yang disuguhkan dengan konsep menjelajahi, sehingga target audiens disini terlibat dalam peranan pemanfaatan sign yang dibuat. Penyajian sign system yang telah dirancang akan dilakukan dengan menempatkan media utama yaitu ikon-ikon dari beberapa spot di persimpangan jalan menuju ke arah spot yang dituju. Dengan peta menjadi media kedua yang berguna sebagai media pendamping yang akan membantu mengarahkan target audiens menuju lokasi yang diinginkan, disinilah target audiens juga turut ikut serta memahami apa yang ada di dalam peta atau media pendamping sehingga target sampai ketempat tujuan hanya dengan mengandalkan rute menuju ikon tersebut tanpa harus khawatir tersesat.

\subsubsection{Pengarahan Pesan Visual}

Adapun untuk mengarahkan pesan visual maka citra visual yang akan digunakan pada perancangan sign system ini yaitu dengan gaya explore (menjelajah) artinya dalam bentuk peta yang di tampilkan memiliki visual yang unik/menarik serta menyenangkan sehingga akan memancing atau mengarahkan target audiens untuk ingin menjelajahi area tempat wisata ini. Tujuannya yaitu agar pesan yang ingin disampaikan dapat tersampaikan secara sempurna. Agar pesan yang ingin disampaikan mudah di baca oleh audiens, maka jenis font yang akan digunakan pada sign system ini yaitu jenis font san serif. Font san serif ini font yang tidak memiliki garis kecil di setiap akhir huruf sehingga font tersebut memiliki kesan tegas. Tone warna yang digunakan pada desain ini menggunakan warna-warna kalem dan warna yang tidak kontras dengan tujuan untuk memberikan kesan klasik ataupun tempo dahulu karena dalam hal ini warna juga memiliki pengaruh yang kuat terhadap sikap dan emosi target audiens.

Layout adalah tata letak elemen-elemen desain terhadap suatu bidang dalam media tertentu untuk mendukung konsep-konsep yang dibawanya (Rustan, 2008). Untuk mendukung konsep supanya pesan yang ingin disampaikan tersampaikan dengan baik, maka ada beberapa prinsip dalam melayout agar menjadi efektif, prinsip ini di kemukakan oleh Frank F. Jefkin diantaranya: kesatuan, variasi, keseimbangan, irama, harmoni, proporsi, dan kontras (Jefkins, 1996). Layout yang akan di gunakan dalam desain sign system ini adalah penekanan (emphasis) dimana layout ini ada bentuk yang ditonjolkan dengan tujuan utama adalah untuk menunjukkan apa yang ditonjolkan supanya dapat mengarahkan pandangan audiens sehingga apa yang mau disampaikan tersalurkan.

Pada perancangan sign system di Air Terjun Tiu Pituq ini, peneliti menggunakan gaya desain Victorian (1837-1901) yaitu gaya desain yang memiliki ciri khas ornamen yang kompleks dalam desainnya. Cenderung menggunakan warna-warna gelap seperti hitam ataupun coklat gaya ini selalu menyatukan border dekoratif dengan dipadukan dengan tipografi sehingga desainnya terlihat menarik. namun dengan suasana tradisional dan kearifan lokal, gaya desain ini merupakan gaya desain yang sederhana, dengan menggunakan warna warna yang khas sesuai dengan sisi tradisional obeyek wisata Tiu Pituq yang ingin dikemas dalam sign system ini. Sehingga diharapkan target audiens 
yang dituju dengan mudah dapat memahami suatu papan informasi yang terkandung didalamnya. Warna termasuk salah satu unsur keindahan dalam seni dan desain selain unsur-unsur visual yang lain (Prawira, 1989). Warna sebagai tanda atau simbol merupakan perlambangan sesuatu yang merupakan tradisi atau pola umum. Kehadiran warna sebagai simbol juga untuk memberikan tanda tertentu yang sudah merupakan satu kebiasaan umum. Demikian eratnya hubungan warna dengan kehidupan manusia, maka warna mempunyai peranan yang sangat penting, yaitu warna sebagai representasi alam, warna sebagai lambang atau simbol, dan warna sebagai simbol ekspresi (Dharsono, 2004). Sedangkan Ilustrasi yang akan digunakan dalam perancangan sign system ini adalah ikon tradisional dekoratif yang menyesuaikan dengan dengan keadaan tempat wisata tersebut, dan juga mudah dilihat mudah diketahui dan dipahami oleh target audiens, sehingga pesan yang ingin disampaikan dapat diterima.

\subsection{Prototype}

\subsubsection{Layout Kasar}

Berikut rancangan sketsa layout kasar yang dibuat oleh peneliti menggunakan pensil

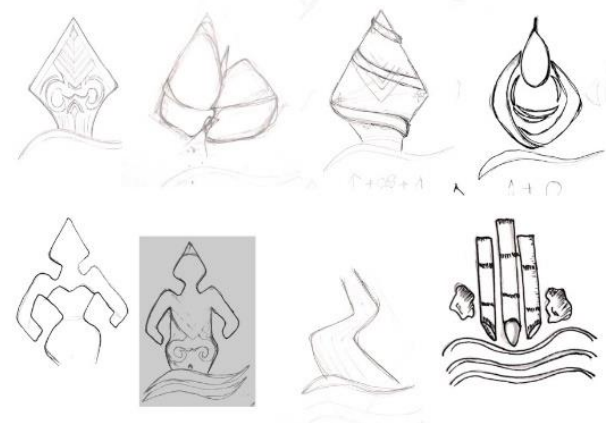

Gambar 2. Sketsa kasar

[Sumber: Dokumentasi penulis]

\subsubsection{Layout Komprehensif}

Berikut hasil rancangan layout komprehensif hasil penyesuain dari rancangan sketsa layout kasar yang telah dibuat peneliti sebelumnya. Layout komprehensif merupakan layout / gambar desain yang sudah mendekati komposisi final.

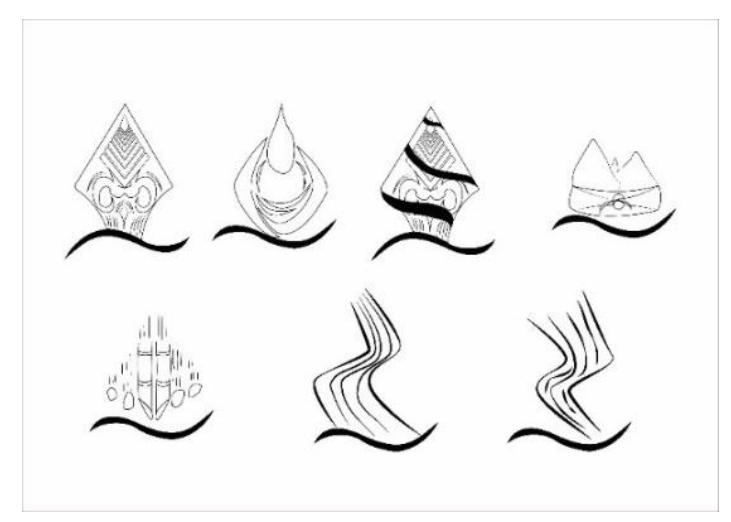

Gambar 3. Komprehensif [Sumber: Dokumentasi penulis] 


\subsubsection{Final Desain}

a. Ikon Tiu Tawah

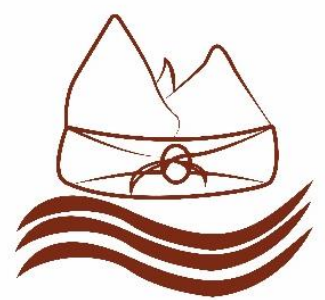

Gambar 4. Final desain tiu tawah

[Sumber: Dokumentasi penulis]

Ikon ini mewakili Tiu Tawah, yang dalam desain ini terdapat ikon sapuk atau ikat kepala khas Lombok yang dominan dipakai oleh keturunan Datu dan lainnya, walaupun tidak menutup kemungkinan sapuk juga dipakai oleh masyarakat biasa, disini juga terdapat juga ikon seperti gelombang air yang yang mewakili bahwa tempat ini merupakan kolam air di sebuah sungai yang dalam bahasa sasak Lombok Utara disebut tiu, jadi ikon ini menjelaskan bahwa ikon sapuk diatas air ini atau hanyut menyampaikan pesan bahwa disinilah terjadi pelepasan atau peleburan kasta yang semula melekat pada diri Arka Sakti Ningrat merupakan cucu dari Patih tempang namun dilepas dan setelah ia mandi ia menjadi masyarakat biasa sama seperti masyarakat atau warga disana.

\section{b. Ikon Tiu Tinggi}

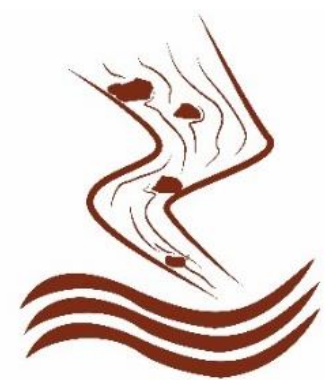

Gambar 5. Final desain tiu tinggi [Sumber: Dokumentasi penulis]

Ikon ini mewakili Tiu Tinggi, yang dalam ikon ini terdapat seperti aliran sungai dari hulu ke hilir yang dibentuk dengan bentuk meninggi. Pada tiu ini tidak ada cerita atau aktivitas, Arka Sakti Ningrat hanya mandi dan berenang ke hulu untuk sampai ke Tiu Tawah. Bentuk ikon yang meninggi mewakili nama dari tiu itu sendiri yang bentuknya memanjang, panjang dalam bahasa Sasak Lombok Utara yang artinya tinggi, maka dari itulah tiu tersebut diberi nama tiu tinggi.

\section{c. Ikon Tiu bunter}

Ikon ini mewakili Tiu bunter, disini terdapat ikon tetesan air dan juga gelombang air yang membentuk lingkaran di tengahnya dalam kata lain disebut juga bundar, pada tiu ini tidak ada cerita atau aktivitas, Arka Sakti Ningrat hanya mandi dan berenang 
ke hulu untuk sampai ke Tiu Tinggi, ikon gelombang air yang membentuk lingkaran disisi mewakili bentuk tiu ataupun kolam air yang terdapat disungai ini, lingkaran yang dalam bahasa Sasak Lombok Utara disebut bunter, di Tiu ini tetesan air mewakili terjunan air yang tidak tinggi atau kurang dari satu meter.

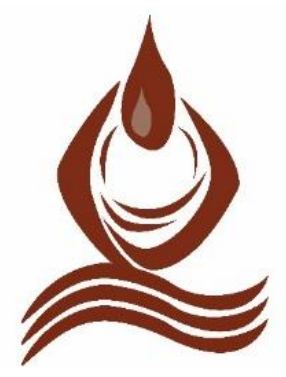

Gambar 6. Final desain tiu bunter [Sumber: Dokumentasi penulis]

\section{d. Ikon Tiu Ras}

Ikon ini mengambil bentuk ujung tombak yang dalam hal ini mewakili kisah ataupun legenda dari Tiu Ras ini sendiri, motif yang ada mewakili motif yang sering kita temukan di kain songket khas Lombok, terdapat juga atap Bale Lumbung yang dalam hal ini mewakili atapun mencitrakan bahwa ini adalah Suku Sasak Lombok.

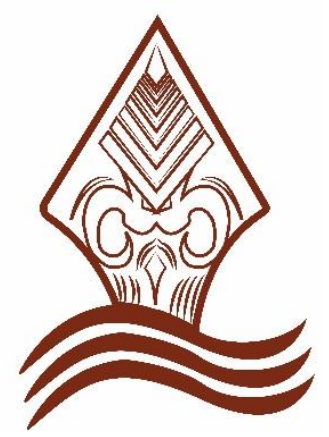

Gambar 7. Final desain tiu ras

[Sumber: Dokumentasi penulis]

Tiga garis melengkung yang tepat berada dibawah ikon mewakili gelombang air. Penggunaan ikon yang berhubungan dengan air karena konsep utama ataupun objek urtama merupakan wisata air terjun.

\section{e. Ikon Tiu Alat-Alat}

Ikon ini mewakili Tiu Alat-Alat, dalam ikon ini terdapat bentuk tombak, yang dalam hal ini menceritakan bahwa di lokasi tiu ini berlangsungnya ritual pemandian dan pembersihan tombak yang akan digunakan untuk menguji dari Arka Sakti Ningrat ini, ritual pembersihan dan pemandian tombak ini divisualkan dengan aliran air yang mengalir mengelilingi ujung tombak sehingga menyampaikan pesan visual membersihkan. Sedangkan ikon gelombang air yang terdapat di bawah ikon utama 
menunjukan tempat terjadinya cerita ataupun ritual ini adalah di sebuah kolam air yang ada di sebuah sungai.

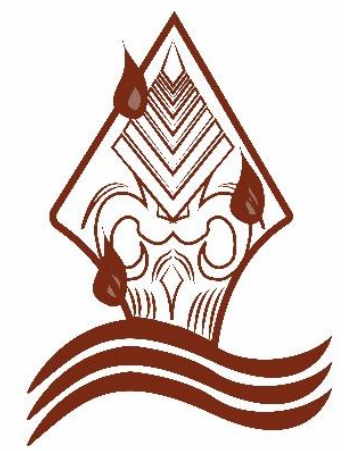

Gambar 8. Final desain tiu alat-alat

[Sumber: Dokumentasi penulis]

\section{f. Ikon Tiu Lesong}

Ikon ini mewakili Tiu Lesong, pada ikon ini terdapat beberapa objek bambu dan batu yang masing-masing memiliki bayangan angin dibelakangnnya seperti melayang atau terjatuh, visual ini mewakili cerita atau aktivitas yang terjadi di tempat ini yaitu ketika Arka Sakti Ningrat diperintahkan oleh sesepuh untuk berdiri di tengah air atau tiu dan di lempar menggunakan batu dan bambu, dalam Bahasa Indonesia lesong berarti lesung yang artinya alat yang biasa digunakan untuk menumbuk sesuatu, jadi visual batu dan bambu dengan bayangan angin dibelakangnya mewakili pesan bahwa disanalah peristiwa pelemparan itu terjadi.

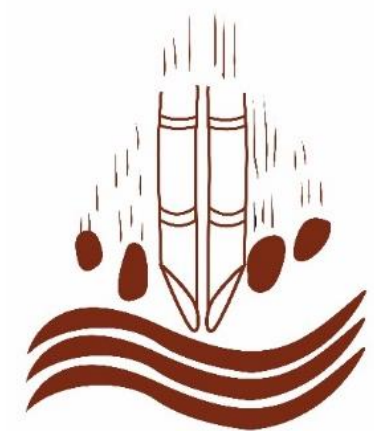

Gambar 9. Final desain tiu lesong

[Sumber: Dokumentasi penulis]

\section{g. Ikon Tiu Rejeng}

Ikon ini mewakili Tiu Rejeng, dalam ikon ini digunakan objek visual yaitu bentuk aliran sungai yang terbalik visual ini digunakan untuk menyampaikan pesan bahwa pada tempat ini sesepuh menguji Arka Sakti Ningrat untuk yang pertama kali untuk membuktikan bahwa ia memang benar merupakan cucu dari Patih Tempang, menggunakan visual aliran air yang berbalik arah tujuannya untuk menceritakan bahwa disana patih tempang yang di dorong ke air apabila ia hanyut ke hilir maka ia tidak dapat dipercaya namun apabila ia hanyut ke hulu maka ia dapat dipercaya. 


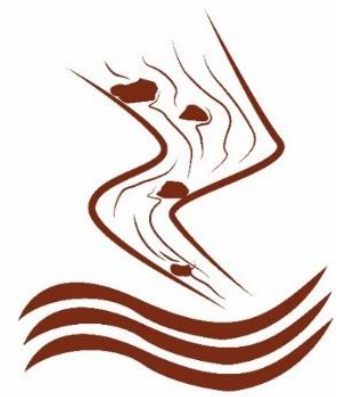

Gambar 10. Final desain tiu rejeng

[Sumber: Dokumentasi penulis]

Pada kenyataannya Arka Sakti Ningrat mampu untuk hanyut ke hulu, oleh karena itulah dengan ikon aliran air terbalik ini digunakan untuk menyampaikan bahwa Arka Sakti Ningrat hanyut ke hulu.

\section{h. Wayfinding Sign}

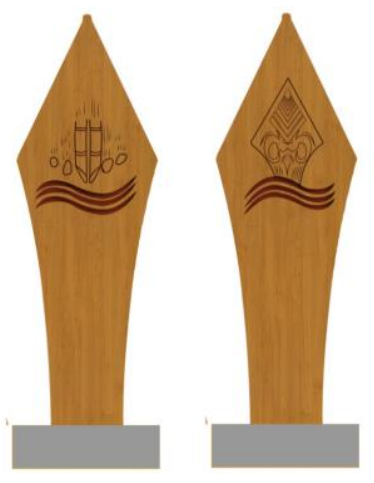

Gambar 11. Final desain Wayfinding sign

[Sumber: Dokumentasi penulis]

Wayfinding ini merupakan media utama dari perancangan ini, Wayfinding ini akan diletakkan di ke tujuh persimpangan jalan menuju setiap tiu yang ada di lokasi tempat wisata tersebut. Media utama perancangan sign system air terjun Tiu Pituq ini memiliki fungsi mengarahkan atau memberi arah dengan menggunakan papan.

\section{i. Directional Sign}

Directional sign pertama ini akan di letakkan pada luar pintu masuk Tiu Pituq. Directional tersebut mengarahkan para pengunjung untuk ke tempat parkir kendaraan. Dan sedangkan untuk gambar kedua akan diletakkan di dalam area lokasi wisata dengan tujuan untuk mengarahkan pengunjung ke toilet. 


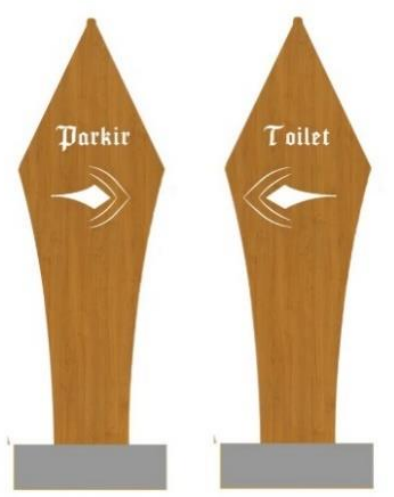

Gambar 12. Final desain Directional Sign

[Sumber: Dokumentasi penulis]

\section{j. Identification Signage}

Identification signage ialah sign yang di tempatkan di ke tujuh lokasi tiu yang dimana hal tersebut mengidentifikasikan destinasi atau tempat tersebut, sama halnya dengan memberitahu para pengunjung bahwa mereka sudah sampai tujuan pada tempat itu.
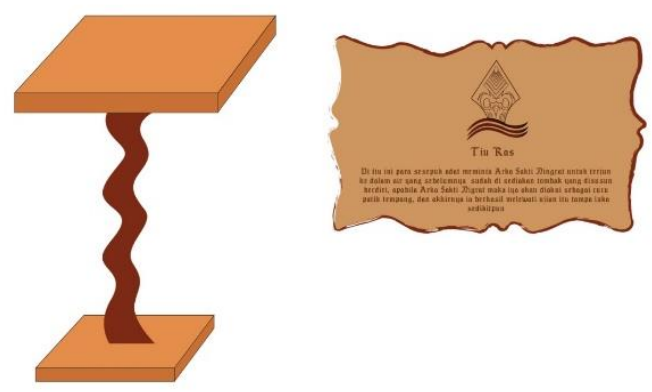

Gambar 13. Final desain identification signage [Sumber: Dokumentasi penulis]

Identification sign yang kedua ialah sign yang di tempatkan di tembok toilet, sign ini mempunyai bentuk yang sama namun di bagi menjadi dua gender yaitu, gender yang ada pada bagian kiri ialah gender pria dan yang kanan ialah gender wanita.

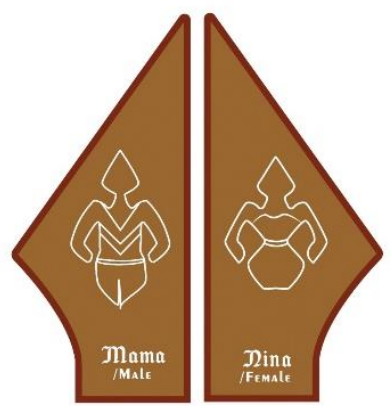

Gambar 14. Final desain sign toilet

[Sumber: Dokumentasi penulis] 


\section{k. Media Pendukung: Peta dan Tiket Masuk}

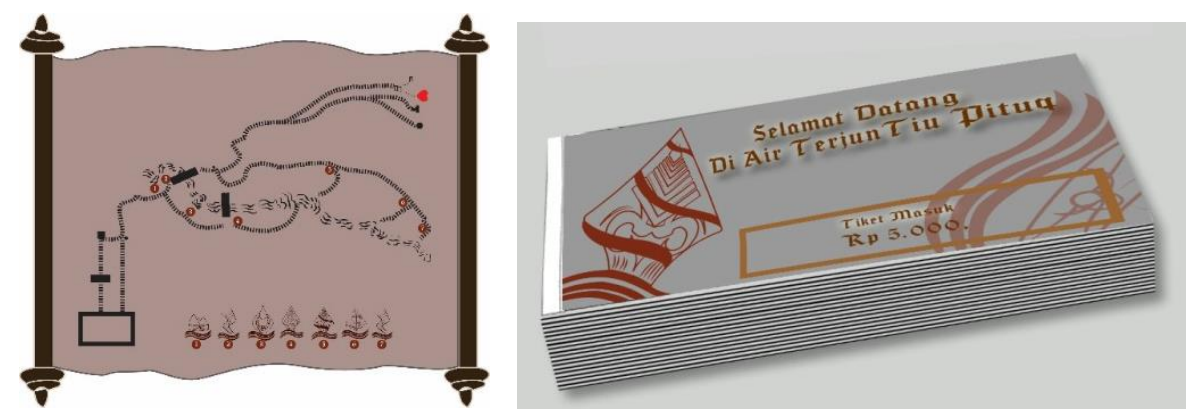

Gambar 15. (Kiri) Final desain Peta dan (kanan) final desain tiket

[Sumber: Dokumentasi penulis]

Peta ini merupakan media pendukung dalam sign system ini, peta disini sebagai penunjuk arah yang mengarahkan pengunjung menuju spot yang ia inginkan.Tiket juga dalam hal ini sebagai media pendukung dimana pengunjung harus memiliki tiket ini untuk dapat memasuki area wisata Tiu Pituq ini.

\subsection{Test}

Untuk mengetahui hasil dari perancangan sign system wisata Air Terjun Tiu Pituq peneliti melakukan uji coba dengan cara menyebarkan kuesioner pada 100 orang responden yang merupakan wisatawan yang mengunjungi wisata Tiu Pituq. Adapun hasil dari kuesioner menunjukkan 97 responden (baca: wisatawan) yang merasa terbantu dengan adanya sign system yang telah dirancang oleh peneliti sementara 3 responden lain merasa tidak terbantu dengan adanya sign system tersebut. Dari hasil kuesioner diatas dapat disimpulkan bahwa penggunaan sign system di wisata Tiu Pituq mendapat respon yang positif sebagai sebuah media petunjuk arah dan informasi tentang wisata Tiu Pituq. Karya desain sign system dengan penerapan konsep tradisional sign system, dengan suasana yang tetap menyatu dengan alam, dimana hal tersebut dapat membuat para pengunjung merasakan atau menikmati suasana alam sekaligus dapat mengetahui cerita rakyat yang terjadi di lokasi wisata tersebut.

\section{KESIMPULAN}

Wisata air terjun Tiu Pituq merupakan wisata baru di Kabupaten Lombok Utara usianya baru beranjak 3 tahun namun perkembangannya sangat pesat sehingga wisata ini dengan cepat dikenal oleh masyarakat. Dengan luas area 2 hektar dan memiliki banyak spot ataupun lokasi, namun pada kenyataannya banyak spot yang tidak dapat dijangkau dan ditemukan oleh pengunjung dengan alasan petunjuk arah yang tidak memadai, hal inilah yang menyebabkan terjadi penumpukan pengunjung di satu spot. Sehingga dapat disimpulkan bahwa untuk memaksimalkan penggunaan fasilitas dan kunjungan ke setiap spot-spot yang tersedia. Peneliti merancang sebuah karya desain sign system pada objek wisata Air Terjun Tiu Pituq ini agar para pengunjung mendapatkan informasi yang maksimal dengan konsep menarik yaitu petualangan. Selain menciptakan petunjuk arah yang efektif, menarik serta kumulatif, peneliti merancang beberapa ikon sesuai 
dengan keberagaman serta legenda ataupun cerita rakyat yang ada di lokasi tersebut sehingga kesannya mampu menunjukan ciri khas dari tempat tersebut.

Sebuah desain sign system tradisional yang dirancang dengan menarik dan efektif tentunya akan membuat para pengunjung merasa terkesan dan mudah mengakses objek wisata Air Terjun Tiu Pituq. Untuk menciptakan suatu sign system (wayfinding) yang efektif dan memiliki ciri khas diperlukan beberapa hal dan langkah mulai dari menetapkan tujuan menentukan jalan, menganalisa profil pengguna, meneliti tingkat kesulitan menemukan jalan, menganalisa kebutuhan desain, menyusun desain sign system, dan yang terakhir mengumpulkan informasi yang detail dan akurat kedalam sistem grafis. Selain itu sebuah desain sign system harus menggunakan penulisan naskah yang mudah dibaca dan dipahami oleh semua pengunjung serta pemilihan warna yang sesuai dengan pesan yang ingin disampaikan. Dalam mengembangan bentuk visual sign sistem yang menarik dan memiliki ciri khas dengan tempat tersebut, peneliti memulai dengan merancang sketsa layout kasar, lalu merancang sebuah layout komprehensif hingga pada akhirnya menemukan sebuah desain final.

\section{DAFTAR PUSTAKA}

Andrijanto, M. (2018). Perancangan Alternatif Sign System sebagai Informasi Lokasi Penjualan di Pasar Legi Kota Gede. JURNAL DESAIN, Volume 05, Nomor 03(Desain Komunikasi Visual), pp. 223 - 234.

Dharsono. (2004). Seni Rupa Modern. Bandung: Rekayasa Sains.

Jefkins, F. F. (1996). Periklanan Edisi 3. Jakarta: erlangga.

Muri, A. Y. (2017). Metode Penelitian Kuantitatif, Kualitatif dan Penelitian Gabungan. Jakarta: Kencana.

Nafisah, S. (2003). Grafika Komputer. Yogyakarta: Graha Ilmu.

Prawira, S. D. (1989). Warna Sebagai Salah Satu Unsur Seni dan Desain. Jakarta: P2LPTK.

Prof. Dr. A. Muri Yusuf, M. (2016). Metode Penelitian Kuantitatif,Kualitatif, \& Penelitian Gabungan. Jakarta: Kencana.

Putra., R. D. M. H. d. I. D. A. D. (2014). Re-Designing Sign System In Kiaracondong Railway Station Bandung. Wiba : Jurnal Komunikasi Visual \& Multimedia, Vol. 6 No.1(Desain Komunikasi Visual \& Multimedia), pp. 11 - 25.

Rustan, S. (2008). Layout, Dasar dan Penerapannya. Jakarta: PT Gramedia Pustaka Utama.

Sabri, M. (2015). Perancangan Sign System Kampung Madras Kota Medan. Jurnal Proporsi, Vol 1, No 1(Kajian Desain, Multimedia dan Industri Kreatif), pp. 90 $-103$.

Swasty, M. F. R. d. W. (2019). Perancangan Media Informasi Kota Tua Jakarta Utara Melalui Sign System Yang Terintegrasi Website. Andharupa : Jurnal Desain Komunikasi Visual \& Multimedia, Vol. 05 No. 02(Desain Komunikasi Visual \& Multimedia), pp. 210 - 225.

Tanuwidjaja, G. (2012). Evaluasi Sistem Wayfinding-People Pada Gedung universitas Surabaya. Surabaya: Universitas Kristen Petra.

Tinarbuko, S. (2009). Semiotika Komunikasi Visual. Yogyakarta: Jalasutra.

Tinarbuko, S. (2012). Semiotika Komunikasi Visual Edisi Revisi. Yogyakarta: Jalasutra. 